\title{
ANALISIS FAKTOR-FAKTOR YANG MEMPENGARUHI UPAH PEKERJA WANITA PEDESAAN DI SUMATERA SELATAN
}

\author{
Lamazi \\ Balai Diklat Provinsi Sumatera Selatan
}

\begin{abstract}
ABSTRAK
Penelitian ini bertujuan untuk menganalisis faktor-faktor yang mempengaruhi upah pekerja wanita di Sumatera Selatan. Penelitian ini menggunakan model persamaan Mincerian sedangkan pengelolaan data dalam penelitian ini menggunakan SPSS. Dari hasil penelitian didapat bahwa variabel usia, jam kerja dan tingkat pendidikan berpengaruh secara signifikan terhadap upah pekerja wanita. Selanjutnya variabel memiliki balita dan status menikah tidak berpengaruh secara signifikan terhadap upah pekerja wanta di Pedesaan. Pada penelitian ini juga ditemukan bahwa upah pekerja wanita di sektor non pertanian lebih rendah dari yang bekerja di sektor pertanian.
\end{abstract}

Kata kunci: Upah, Pekerja Wanita, Pedesaan, sektor non pertanian.

\section{Latar Belakang}

Partisipasi angkatan kerja (PAK) wanita di dunia ketiga meningkat secara dramatis pada tahun 1990. Terutama bagi negara-negara di kawasan Asia meningkat sampai $4,3 \%$. Namun kebanyakan dari kaum wanita tersebut bekerja di sektor pertanian $(80 \%)$ atau sektor informal antara 25\% sampai $40 \%$ (Todaro, 2000). Fenomena serupa juga terjadi di Indonesia dimana dalam kurun waktu lima puluh tahun telah terjadi peningkatan hampir dua kali lipat.

Tingkat Partisipasi Angkatan Kerja (TPAK) wanita berdasarkan Sensus Penduduk 1961 yaitu sebesar 29,35\% (Oey, 2005) meningkat menjadi 52,44\% ditahun 2011 (BPS,2013).Hal yang sama juga terjadi di Sumatera Selatan. Kecenderungan perubahan TPAK di Sumatera Selatan sejak tahun 2006-2013 dapat dilihat dalam Tabel 1.1.

Tabel 1.1

Tingkat Partisipasi Angkatan Kerja Menurut Jenis Kelamin di Sumatera Selatan Tahun $2006-2013$.

\begin{tabular}{|l|l|l|l|l|l|lll|}
\hline \multirow{2}{*}{$\begin{array}{l}\text { Jenis } \\
\text { Kelamin }\end{array}$} & \multicolumn{6}{|c|}{ Tingkat PartisipasiAngkatan Kerja (\%) } \\
\cline { 2 - 7 } & $\mathbf{2 0 0 6}$ & $\mathbf{2 0 0 7}$ & $\mathbf{2 0 0 8}$ & $\mathbf{2 0 0 9}$ & $\mathbf{2 0 1 1}$ & $\mathbf{2 0 1 2}$ & $\mathbf{2 0 1 3}$ \\
\hline$(1)$ & $(2)$ & $(3)$ & $(4)$ & $(5)$ & $(7)$ & $(8)$ & $(9)$ \\
\hline Pria & 86,01 & 84,15 & 85,35 & 84,58 & 85,32 & 87,28 & 85,40 \\
\hline Wanita & 53,39 & 54,02 & 54,06 & 51,88 & & 57,31 & 59,44 & 58,10 \\
\hline Pria+Wanita & 69,64 & 69,03 & 69,79 & 63,31 & 71,51 & 73,55 & 71,94 \\
\hline
\end{tabular}

Sumber: Sakernas 2006 - 2013, BPS

Secara keseluruhan, TPAK wanita berada dalam kisaran $2 / 3$ di bawah TPAK pria. Hal ini menunjukkan masih terdapat penghalang bagi wanita untuk memasuki pasar kerja, salah satu diantaranya adalah faktor mengurus rumah tangga. Secara teoritis dan empiris, tidak bekerjanya istri merupakan suatu kerugian bagi ekonomi rumah tangga (Boll, 2011) sehingga adanya kecenderungan peningkatan PAK wanita memberikan indikasi awal semakin membaiknya tingkat kesejahteraan keluarga. Meskipun dalam rumah tangga, upah pekerja wanita cenderung sebagai pendapatan sampingan (secondary sources), namun upah tersebut berperanan penting bagi ekonomi rumah tangga (Stallman, 1992). Telah menjadi maklum 
bahwa faktor pendorong utama wanita turut serta dalam aktivitas ekonomi didorong oleh adanya kemiskinan (Tarmizi, 2003). Namun, seberapa besar kontribusi penghasilan wanita bagi peningkatan kesejahteraan rumah tangga bergantung kepada banyak faktor. Salah satu faktor yang perlu dihilangkan adalah adanya diskriminasi upah bagi pekerja wanita.

Adanya diskriminasi terhadap pekerja wanita menjadikan upah yang diterimanya lebih rendah dari pekerja pria (Killingsworth, 1991; Todaro, 2000). Perbedaan upah bagi pekerja wanita bukan saja berdasarkan gender tetapi juga terjadi berdasarkan wilayah. Pada beberapa penelitian menunjukan bahwa terdapat perbedaan upah bagi pekerja wanita yang tinggal di pedesaan dibandingkan pekerja wanita di perkotaan. Diskriminasi upah bagi pekerja wanita juga terjadi di Sumatera Selatan sebagaimana terlihat dari data yang disajikan dalam Tabel 1.2.

Tabel 1.2

Rata-Rata Upah dan Jam Kerja Perminggu Berdasarkan Gender dan Status

Kewilayahan di Sumatera Selatan tahun 2013

\begin{tabular}{|l|l|l|l|l|}
\hline \multirow{2}{*}{$\begin{array}{l}\text { Status } \\
\text { kewilayahan }\end{array}$} & $\begin{array}{l}\text { Jenis } \\
\text { Kelamin }\end{array}$ & $\begin{array}{l}\text { Rata-rata } \\
\text { upah (Rp) }\end{array}$ & $\begin{array}{l}\text { Rata- } \\
\text { rata } \\
\text { jam } \\
\text { kerja/ } \\
\text { minggu }\end{array}$ & $\begin{array}{l}\text { Rata- } \\
\text { rata } \\
\text { upah/ } \\
\text { jam (Rp) }\end{array}$ \\
\hline$(1)$ & $(2)$ & $(3)$ & $(4)$ & $(5)$ \\
\hline \multirow{2}{*}{ Perkotaan } & Pria & $1.005 .205,05$ & 24.76 & $40.497,82$ \\
\cline { 2 - 5 } & Wanita & $372.769,51$ & 14,43 & $25.883,95$ \\
\hline \multirow{2}{*}{ Pedesaan } & Pria & $729.650,28$ & 23,13 & $31.554,62$ \\
\cline { 2 - 5 } & Wanita & $176.966,74$ & 14,16 & $12.497,65$ \\
\hline
\end{tabular}

Sumber: SUSENAS 2013, diolah

Tabel 1.2 menunjukan terdapat perbedaan yang besar antara rata-rata upah pekerja wanita perjam yang tinggal di pedesaan dengan perkotaan yaitu sebesar Rp. 25.883,95 untuk daerah perkotaan dibandingkan dengan Rp. 12.497,65 untuk pekerja wanita yang tinggal di pedesaan. Secara prosentase perbedaan upah antara pekerja wanita yang tinggal di perkotaan dan pedesaan mencapai $48,28 \%$. Oleh karena itu, peneliti tertarik untuk mendalami fenomena adanya diskriminasi upah tersebut. Berdasarkan dari Fenomena diatas peneliti tertarik untu meneliti fakfaktorapa saja yang mempengaruhi upah pekerja wanita di pedesaan di Provinsi Sumatera Selatan.

\section{Tujuan Penelitian}

Penelitian ini bertujuan untuk menjelaskan: faktor-faktor apa sajakah yang mempengaruhi upah bagi pekerja wanita di Pedesaan Provinsi Sumatera Selatan.

\section{Manfaat Penelitian}

Manfaat hasil penelitian ini diharapkan :

1. Secara teoritis, diharapkan berguna bagi pengembangan ilmu pengetahuan.

2. Secara praktis, diharapkan berguna sebagai bahan masukan dalam pengembangan model pengupahan yang lebih adil (non diskriminatif) di Sumatera Selatan.

\subsection{Landasan Teori}

\subsubsection{Teori Pilihan Bekerja atau Waktu Senggang (Leisure)}

Asumsi dasar pada teori ini adalah pilihan tenaga kerja dalam memaksimalkan utilitasnya apakah lebih banyak mengkonsumsi barang atau waktu senggang (leisure) jika dihubungkan dengan tingkat upah. Teori ini lebih dikenal dengan sebutan teori pilihan laborleisure (Ehrenberg, 2003; Kaufman, 2003; Borjas, 2005).

Dalam sehari semalam seseorang mempunyai waktu 24 jam. Dari keterbatasan waktu tersebut, seseorang individu harus mengalokasikan waktunya untuk bekerja atau untuk waktu senggang (laisure) (P. Cahuc, 2004). Dimaksud bekerja adalah waktu yang disediakan untuk pekerjaan yang dibayar, sedangkan waktu senggang adalah waktu yang disediakan bagi semua aktifitas yang tidak dibayar contoh bekerja di rumah tangga, konsumsi, pendidikan, berjalan, istirahat dan santai (Compbel, 2006). Dalam menentukan pilihan bekerja atau waktu 
senggang, dipengaruhi oleh tiga hal yaitu (1) opportunity cost merupakan nilai dari waktu senggang, (2) preferensi pekerja merupakan persepsi seseorang terhadap barang dan jasa dan (3) selera (Nurlina, 2012).

Secara matematis hubungan antara konsumsi dan waktu senggang dinotasikan dalam suatu fungsi yang dikenal dengan fungsi utiliti yang dituliskan dalam Persamaan (1).

$\mathrm{U}=\mathrm{f}(\mathrm{C}, \mathrm{L})$

Dalam memaksimumkan tingkat kepuasan, seseorang akan menghadapi konstrain anggaran. Konstrain anggaran adalah kurva yang terdiri dari kombinasi antara pendapatan dan waktu sengang (leisure) dimana tingkat upah konstan. Terdapat dua konstrain anggaran dalam memaksimalkan utiliti yaitu (1) waktu yang dipergunakan untuk bekerja dan (2) pendapatan.

Dari sisi pendapatan, ada dua konstrain anggaran yaitu (1) memiliki pendapatan dari luar upah (non labor income) dan (2) memiliki pendapatan hanya dari upah. Bagi pekerja yang hanya memiliki pendapatan dari upah maka persamaan konstrainnya adalah:

$\mathrm{C}=\mathrm{wh}$

Sedangkan hubungan dengan waktu, persamaan konstrainnya ditulis menjadi:

$\mathrm{L}+\mathrm{h}=24$ atau $\mathrm{h}=24-\mathrm{L}(3)$

Dengan mensubstitusikan persamaan (3) ke dalam persamaan (2) maka persamaan konstrain anggarannya menjadi:

$\mathrm{C}=24 \mathrm{w}-\mathrm{wL}$

Bagi pekerja yang mempunyai pendapatan dari non-labor income (V) maka persamaan konstrain anggarannya ditulis sebagai berikut:

$\mathrm{C}=\mathrm{wh}+\mathrm{V}$
Dengan mensubstitusikan persamaan (3) ke dalam persamaan (5) maka persamaan konstrain anggarannya menjadi:

$C=(24 w+V)-w L(6)$

Tanda negatif pada w menunjukan slope konstrain anggaran negatif untuk menawarkan jasa tenaga kerjanya di pasar kerja.

\subsection{Teori Mutu Modal Manusia (Human Capital)}

Adanya modal manusia sebagai prediktor tingkat upah (kesenjangan upah) dikemukakan oleh Becker (1980) dan Mincer (1974). Teori human capital berangkat dari asumsi dasar bahwa peningkatan pendidikan seseorang memberikan pengaruh terhadap peningkatan pendapatan (Kaufman dan Hotchkiss, 2006). Hal ini dikarenakan secara empiris apabila seseorang meningkat tingkat pendidikanya maka orang tersebut juga akan mengalami peningkatan keahlian yang berdampak pada peningkatan upah yang diterima. Dalam konteks ini, perbedaan upah dipengaruhi oleh perbedaan produktivitas individu yang juga dipengaruhi oleh investasi human capitalnya dalam pendidikan atau training (Cahuc, 2004). Meskipun tingkat pendidikan diketahui dapat meningkatkan penghasilan, namun keputusan seseorang dalam melanjutkan pendidikan juga dipengaruhi oleh selisih antara opprtunity cost dengan jumlah kumulatif pendapatan yang akan diterima nantinya sebagai kompensasi masa pendidikan.

Dalam mempengaruhi upah, Reynold (1998) mengemukakan terdapat dua hal penting yaitu: pertama, selama mengikuti pendidikan upah akan menurun karena individu lebih banyak waktunya (opportunity cost) terlibat dalam kehadiran di sekolah daripada bekerja. Kedua, upah akan meningkat setelah menamatkan pendidikanya. Untuk lebih jelasnya lihat Gambar 2.2 berikut ini: 


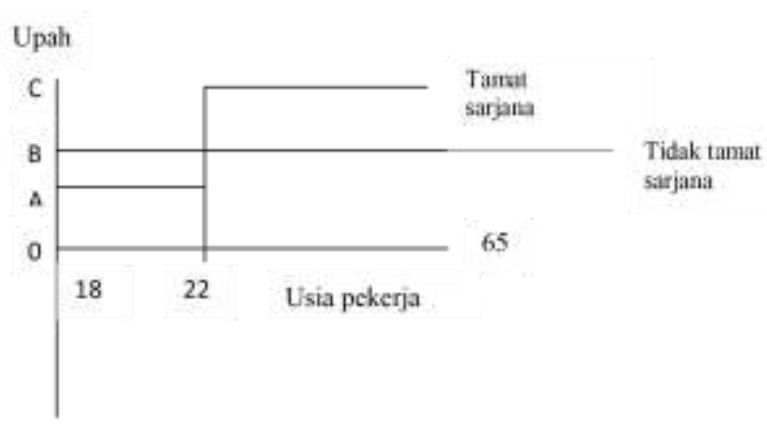

Sumber: Reynold, 1998.

Gambar 2.2. Hubungan Usia, Pendidikan dan Profil Upah

Pada Gambar 2.2 menunjukan ketika sedang melakukan pendidikan, upahnya sebesar OA, ini didapat dari bekerja part time atau musiman. Sementara bagi pekerja yang tidak menlanjutkan pendidikan, upah yang diterimanya sebesar OB dengan full-time setiap tahunya. Opportunity cost sebesar AB karena melakukan sekolah atau human capital lainnya. Namun, setelah selesai melakukan pendidikan upah meningkat sebesar BC, sehingga upah yang diterima sebesar OC.

Teori human capital berusaha menjelaskan perbedaan upah sebagai kosekuensi dari perbedaan stok modal manusia yang menentukan produktivitas marjinal individu. Human capital merupakan stok pengetahuan, keterampilan, bakat, pendidikan, dan pelatihan yang dimiliki setiap individu sehingga bersifat heterogen dalam pasar tenaga kerja.

\subsection{Studi Terdahulu}

Berikut ini terdapat beberapa penelitian yang menunjang penelitian ini mengenai faktor yang mempengaruhi upah pekerja wanita.

Hall (1973 ) meneliti tentang jam kerja , upah dan pendapatan bagi wanita di Amerika Serikat. Hasil penelitian menunjukan jam kerja wanita menikah berhubungan negatif terhadap jumlah orang dewasa dalam keluarga dan kehadiran anak. Bagi wanita yang belum menikah menunjukan respon positif antara jam kerja dan kelompok upah rendah dan bertanda negatif pada kelompok upah tinggi.

Nakamura (1979) dalam penelitian tentang jam kerja dan upah bagi tenaga kerja wanita menikah. Pada penelitian tersebut tenaga kerja wanita menikah dikelompokkan berdasarkan usia yaitu menjadi delapan kelompak. Untuk melihat variabel upah sebagai endogen di estimasi dengan OLS. Hasil penelitian menunjukan pendidikan dan usia berpengaruh positif dan signifikan terhadap upah. Begitu juga halnya dengan variabel jumlah anak dibawah 6 tahun. Variabel ini bertanda negatif dan signifikan terhadap upah tenaga kerja wanita. Pada variabel jam kerja sebagai variabel endogen di estimasi menggunakan 2SLS, hasil penelitian menunjukan variabel upah, jumlah anak dibawah 6 tahun dan anak berusia $6-14$ tahun, variabel pendapatan suami dan asset keluarga bertanda negatif dan signifikan terhadap jam kerja. Sedangkan pendapatan anggota keluarga per-orang di luar dirinya bertanda positif dan signifikan.

Katherine (1992) dalam penelitian tentang partisipasi tenaga kerja wanita dan upah di Jamaika menyebutkan bahwa variabel upah sebagai varibel endogen dipengaruhi oleh variabel pengalaman dan tahun kuadrat. Dari hasil penelitian tersebut bahwa variabel lama sekolah berpengaruh signifikan dan positif terhadap upah. Penelitian tentang partisipasi tenaga kerja wanita dan upah juga diteliti oleh Carolin Winter( 1992) di Honduras pada penelitian tersebut disebutkan bahwa fungsi upah di pengaruhi oleh lama tahun sekolah, jam kerja dan pengalaman. Dari hasil penelitian bagi tenaga kerja wanita yang bekerja disemua sektor menunjukkan bahwa variabel lama sekolah, jam kerja dan pengalaman berpengaruh secarak signifikan dan positif terhadap upah. Hal yang sama terjadi juga di sektor formal.

Penelitian yang sama juga dilakukan Bolovia oleh Katherine M Scoth (1992) hasil penelitianya menunjukkan bahwa 
fungsi upah di pengaruhi oleh lama tahun sekolah, jam kerja dan pengalaman. Dari hasil penelitian bagi tenaga kerja wanita yang bekerja disemua sektor menunjukan bahwa variabel lama sekolah, jam kerja dan pengalaman berpengaruh secarak signifikan dan positif terhadap upah.

Ozdemir (2006) meneliti tentang penawaran tenaga kerja wanita di sektor informal di Turki dengan menggunakan jam kerja perhari sebagai ukuran variabel dependen. Penelitian ini menggunakan pendekatan logit dalam mengukur jam kerja. Hasil penelitian menyimpulkan bahwa upah secara umum berpengaruh negatif pada jam kerja, sedangkan jika upah dikelompokkan menjadi 7 kelompok berdasarkan besarnya upah menunjukan bahwa pada kelompok upah dari 1 sampai enam berpengaruh positif (pengaruh substitusi mendominasi pengaruh pendapatan).

\subsection{Kerangka Pemikiran}

Pada penelitian ini yang dipertimbangkan sebagai variabel independennya adalah: tempat tinggal, pendidikan, usia, sektor pekerjaan, jam kerja, status menikah, memiliki anak 5 tahun ke bawah dalam keluarga. Beberapa dari Gambar 2.6 berikut ini:

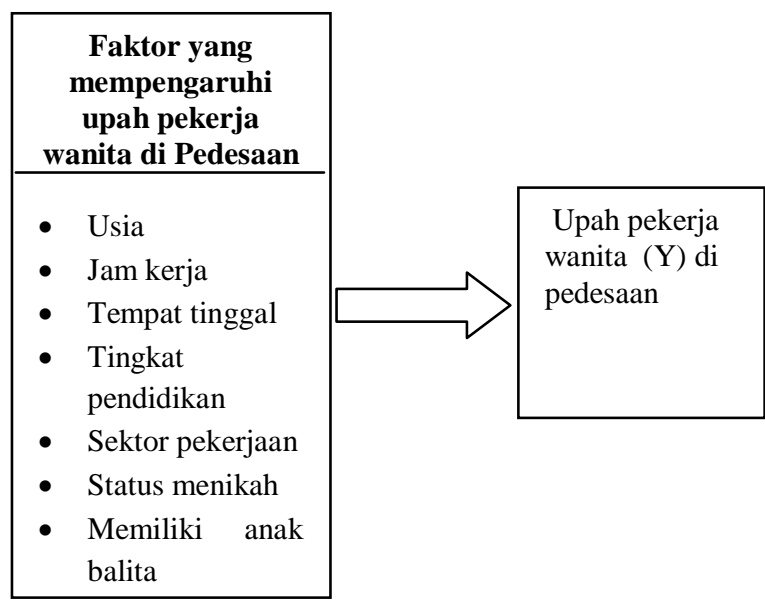

Gambar 2.6 Kerangka Pemikiran

\subsection{Hipotesis}

Hipotesis disusun berdasarkan panduan studi pustaka sebelumnya, serta nantinya akan dibuktikan secara empiris melalui analisis deskriptif maupun analisis inferensial. Adapun hipotesis yang diajukan adalah sebagai berikut:

1. Diduga upah pekerja wanita Pedesaan di Sumatera Selatan dipengaruhi secara signifikan oleh:usia, jam kerja, wilayah tempat tinggal, tingkat pendidikan, sektorpekerjaan, status menikah dan memiliki anak balita.

\section{PEMBAHASAN}

\subsection{Ruang Lingkup Penelitian}

Penelitian ini menggunakan pendekatan kuantitatif, bersifat hipothetical testing dan potong lintang (cross-section). Wilayah penelitian mencakup keseluruhan Sumatera Selatan.

\subsection{Jenis dan Sumber Data}

Jenis data yang digunakan dalam penelitian ini adalah data mentah (raw data) bersumber dari Survei Sosial Ekonomi Nasional (SUSENAS) Tahun 2013. Data SUSENAS dikumpulkan oleh Badan Pusat Statistik (BPS) dengan mempergunakan Multi Stage Random Sampling Desig. Pemilihan data SUSENAS dikarenakan modul yang dipergunakan mengandung semua variabel penelitian yang dibutuhkan. Selain bersumber raw data SUSENAS 2013, penelitian ini juga menggunakan data sekunder yang bersumber dari publikasi institusi yang dapat diverifikasi kejelasan sumbernya.

\subsection{Prosedur Penentuan Sampel}

Populasi dalam penelitian ini adalah seluruh pekerja wanita penerima upah yang berdomisili di wilayah Sumatera Selatan sedangkan sampel penelitian adalah pekerja wanita penerima upah yang berdomisili di wilayah Sumatera Selatan dan terdata di dalam Survei Sosial Ekonomi Nasional 2013. Secara spesifik, karakteristik populasi dan sampel adalah sebagai berikut:

1. Pekerja wanita yang menerima upah yaitu pegawai (pemerintahan 
maupun swasta) atau buruh (pertanian dan non pertanian) atau pekerja bebas yang menerima upah.

2. Berdomisili di Pedesaan Sumatera Selatan.

3. Berusia 15 tahun ke atas

Jumlah responden seluruhnya yang digunakan dalam penelitian sebanyak sebanyak 813 orang pekerja wanita pedesaan.

\subsection{Prosedur Pengumpulan Data SUSENAS 2013}

Pengumpulan data dilakukan oleh para Mantri dari Badan Pusat Statistik di masing-masing daerah di seluruh Indonesia. Mereka mewawancarai para responden terpilih yang berpedoman pada kuisioner yang telah dibuat oleh BPS yaitu model VSEN2013 (terlampir). Pemilihan responden dilakukan secara bertingkat (Multi Stage Random Sampling Design) oleh BPS Republik Indonesia.

\subsection{Definisi Operasional Variabel}

Untuk memperjelas definisi variabel dan menghindari terjadinya bias penafsiran maka definisi variabel dan kodifikasi variabel dijabarkan dalam Tabel 3.1 .

Tabel 3.1

\section{Definisi Operasional dan Kodifikasi Variabel}

\begin{tabular}{|c|c|c|}
\hline Variabel & Definisi & Operasionalisasi \\
\hline Upah & $\begin{array}{l}\text { Pendapatan } \\
\text { bersih (uang } \\
\text { atau barang) } \\
\text { yang biasanya } \\
\text { diterima } \\
\text { sebulan dari } \\
\text { pekerjaan } \\
\text { utama (Rp). }\end{array}$ & $\begin{array}{l}\text { ditransformasikan } \\
\text { bentuk logaritma natural, } \\
\text { lambang: ln (upah) }\end{array}$ \\
\hline Usia & $\begin{array}{lr}\text { Usia } & \text { pekerja } \\
\text { wanita } & \text { dalam } \\
\text { tahun } & \text { menurut } \\
\text { ulang } & \text { tahun } \\
\text { terakhir } & \\
\end{array}$ & $\begin{array}{l}\text { ditansformasikan } \\
\text { bentuk logaritma natural, } \\
\text { lambang: } \ln (\text { usia })\end{array}$ \\
\hline Jam kerja & $\begin{array}{rr}\text { Jumlah } & \text { jam } \\
\text { pekerja } & \text { wanita } \\
\text { bekerja } & \text { selama } \\
\end{array}$ & $\begin{array}{l}\text { ditransformasikan dalam } \\
\text { bentuk logaritma natural, } \\
\text { lambang: } \ln (\text { jam kerja) }\end{array}$ \\
\hline
\end{tabular}

\begin{tabular}{|c|c|c|}
\hline & $\begin{array}{l}\text { seminggu yang } \\
\text { lalu (dalam } \\
\text { jam) }\end{array}$ & \\
\hline $\begin{array}{l}\text { Tingkat } \\
\text { Pendidikan }\end{array}$ & $\begin{array}{l}\text { Ijazah tertinggi } \\
\text { yang dimiliki }\end{array}$ & Kategori \\
\hline $\mathrm{SD}$ & $\begin{array}{l}\text { Pekerja wanita } \\
\text { yang memiliki } \\
\text { ijazah SD }\end{array}$ & $\begin{array}{l}\text { bernilai } 1 \text { apabila memiliki } \\
\text { ijazah SD; bernilai } 0 \text { apabila } \\
\text { selainnya }\end{array}$ \\
\hline SMP & $\begin{array}{l}\text { Pekerja wanita } \\
\text { yang memiliki } \\
\text { ijazah SMP }\end{array}$ & $\begin{array}{l}\text { bernilai } 1 \text { apabila memiliki } \\
\text { ijazah SMP; bernilai } 0 \text { apabila } \\
\text { selainnya }\end{array}$ \\
\hline SMA & $\begin{array}{l}\text { Pekerja wanita } \\
\text { yang memiliki } \\
\text { ijazah SMA }\end{array}$ & $\begin{array}{l}\text { bernilai } 1 \text { apabila memiliki } \\
\text { ijazah SMA; bernilai } 0 \text { apabila } \\
\text { selainnya }\end{array}$ \\
\hline Dikti & $\begin{array}{l}\text { Pekerja wanita } \\
\text { yang memiliki } \\
\text { ijazah Diploma, } \\
\text { Sarjana dan } \\
\text { Pascasarjana }\end{array}$ & $\begin{array}{l}\text { bernilai } 1 \text { apabila memiliki } \\
\text { ijazah } \\
\text { Diploma/Sarjana/Pascasarjana; } \\
\text { bernilai } 0 \text { apabila selainnya }\end{array}$ \\
\hline $\begin{array}{l}\text { Sektor } \\
\text { pekerjaan }\end{array}$ & $\begin{array}{l}\text { Lapangan usaha } \\
\text { atau bidang } \\
\text { pekerjaan } \\
\text { utama dari } \\
\text { tempat } \\
\text { pekerjaan } \\
\text { selama } \\
\text { seminggu } \\
\text { terakhir bekerja }\end{array}$ & $\begin{array}{l}\text { bernilai } 1 \text { apabila non sektor } \\
\text { pertanian; bernilai } 0 \text { apabila } \\
\text { lainnya }\end{array}$ \\
\hline $\begin{array}{l}\text { Status } \\
\text { menikah }\end{array}$ & $\begin{array}{l}\text { status } \\
\text { pernikahan }\end{array}$ & $\begin{array}{l}\text { bernilai } 1 \text { apabila menikah, } \\
\text { bernilai } 0 \text { apabila selainnya }\end{array}$ \\
\hline $\begin{array}{l}\text { Memiliki } \\
\text { balita }\end{array}$ & $\begin{array}{l}\text { Memiliki anak } \\
\text { usia } 5 \text { tahun ke } \\
\text { bawah }\end{array}$ & $\begin{array}{l}\text { bernilai } 1 \text { apabila memiliki } \\
\text { anak balita; bernilai } 0 \text { apabila } \\
\text { selainnya }\end{array}$ \\
\hline
\end{tabular}

\subsection{Model penelitian}

Data yang dianalisis adalah datapekerja wanita yang mendapat upah. Data di analisis menggunakan dua model yaitu 1) model persamaan upah Mincer yang sudah dimodifikasi. Adapun model dalam penelitian ini adaahsebagai berikut:

$$
\begin{aligned}
Y= & a_{o}+a_{1} X_{1}+a_{2} X_{2}+a_{3} X_{3 D}+a_{4} X_{4 D}+a_{5} X_{5 D}+ \\
& a_{6} X_{6 D}+a_{7} X_{7 D}+a_{8} X_{8 D}+a_{9} X_{9 D}+e
\end{aligned}
$$

Dimana :

$$
\begin{array}{ll}
\mathrm{Y} & =\ln (\text { upah }) \\
\mathrm{X}_{1} & =\ln (\text { usia }) \\
\mathrm{X}_{2} & =\ln (\text { jam kerja }) \\
\mathrm{X}_{3 \mathrm{D}} & =\text { Tingkat pendidikan SD }(\text { dummy) } \\
\mathrm{X}_{4 \mathrm{D}} & =\text { Tingkat pend SMP }(\text { dummy }) \\
\mathrm{X}_{5 \mathrm{D}} & =\text { Tingkat pend SMA (dummy) } \\
\mathrm{X}_{6 \mathrm{D}} & =\text { Tingkat pend Dikti (dummy) } \\
\mathrm{X}_{7 \mathrm{D}} & =\text { Sektor pekerjaan (dummy) } \\
\mathrm{X}_{8 \mathrm{D}} & =\text { Status menikah }(\text { dummy }) \\
\mathrm{X}_{9 \mathrm{D}} & =\text { memiliki balita (dummy) } \\
\mathrm{a}_{0,1, ., \mathrm{n}} & =\text { intersep dan koefisien variabel } \\
\mathrm{e} & =\text { error term }
\end{array}
$$




\subsection{Metode Analisis Ekonometrika}

Analisis ekonometrika pada penelitian ini menggunakan data cross section dengan maksud untuk menganalisis faktor-faktor yang mempengaruhi perbedaan upah pekerja wanita pedesaan di Sumatera Selatan. Adapun yang menjadi variabel dependen adalah upah pekerja wanita. Sementara yang menjadi variabel independennya adalah: usia, jam kerja, tingkat pendidikan, sektor pekerjaan, status menikah, memilik balita.

\section{Hasil dan Pembahasan.}

Guna membahas penelitian ini, dengan menggunakan model Mincerian. Selanjutnya data diuji secara statistik (uji asumsi klasik, uji Normalitas). Sementara itu, dalam mengelolah data menggunakan program SPSS. selanjutnya akan dijelaskan hubungan antara variabel upah dengan variabel independen bagi pekerja wanita pedesaan di Sumatera Selatan.

\subsubsection{Hubungan Variabel Independen Penelitian Dengan Upah Pekerja Wanita Pedesaan.}

Untuk menjelaskan pengaruh dari variabel independen terhadap upah pekerja wanita Pedesaan di Sumatera Selatan dapat dilihat pada Tabel dibawah ini:

Tabel. 4.1

Nilai Estimasi Parameter Variabel Independen Terhadap Upah Pekerja Wanita Berdasarkan Wilayah di Sumatera Selatan Tahun 2013

\begin{tabular}{|l|l|l|l|}
\hline \multirow{2}{*}{ Variabel } & \multicolumn{3}{|c|}{} \\
\cline { 2 - 4 } & \multicolumn{3}{|l}{ Pedesaan } \\
\cline { 2 - 4 } & $\boldsymbol{\beta}$ & S.E. & P> t \\
\hline$(1)$ & $(2)$ & $(3)$ & $(4)$ \\
\hline Konstanta & $10,003^{*}$ & 0,3704 & 0,000 \\
\hline Ln (Usia) & $0,8188^{*}$ & 0,0913 & 0,000 \\
\hline Ln (Jam kerja) & $0,2822^{*}$ & 0,0395 & 0,000 \\
\hline Tingkat pendidikan & & & \\
\hline SD & $0,2032^{*}$ & 0,0775 & 0,000 \\
\hline SMP & $0,3310^{*}$ & 0,1055 & 0.002 \\
\hline SMA & $0,7427^{*}$ & 0,1009 & 0,000 \\
\hline \multicolumn{1}{|c|}{ Dikti } & $1,2817^{*}$ & 0,1023 & 0,000 \\
\hline
\end{tabular}

\begin{tabular}{|l|l|l|l|}
\hline Non Pertanian & $-0,3561^{*}$ & 0,0678 & 0,000 \\
\hline Menikah & 0,0854 & 0,071 & 0,181 \\
\hline Memilik anak balita & $-0,1103$ & 0,0650 & 0,090 \\
\hline R $\left.^{2} \%\right)$ & & 29,0 & \\
R $^{2}$ Ajust (\%) & & 28,1 & \\
\hline DW & & & \\
\hline F & & $\begin{array}{l}33,278 \\
<0,01\end{array}$ \\
Signifikansi & & \\
\hline
\end{tabular}

Sumber:SUSENAS 20013, diolah; * = sigifikan pada $\alpha=5 \%$; Dependen variabel $=\ln ($ upah $)$

Model persamaan upah pekerja wanita pedesaan di Sumatera Selatan adalah sebagai berikut:

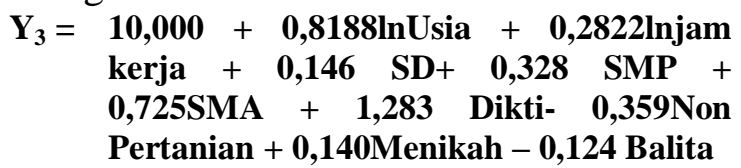

Berdasarkan tabel dan model persamaan di atas, berikut ini akan dijelaskan satu persatu variabel yang mempengaruhi upah pekerja wanta di Sumatera Selatan.

Variabel ln jam kerja berpengaruh secara signifikan dan positif terhadap ln upah di Pedesaan. Nilai estimasi sebesar 0,282 bermakna setiap peningkatan ln jam kerja sebesar 1 persen akan meningkatkan rata-rata upah pekerja wanita di pedesaan sebesar0,28 persen. Pada Variabel Usia berpengaruh secara positif dan signifikan. Nilai koefisien regresi sebesar 0,818 bermakna setiap peningkatan usia sebesar 1 persen akan meningkatkan upah 0,710 persen bagi pekerja wanita pedesaan di Sumatera Selatan.

Variabel pendidikan pada penelitian ini dibagi pada 4 kategori dengan variabel tidak tamat SD sebagai basis kategorinya. Kategori tersebut meliputi: pendidikan SD sederajat, pendidikan SMP sederajat, SMA sederajat dan perguruan tinggi. Pada semua tingkatan nilai estimasinya bertanda positip. Pada variabel pendidikan SD berpengaruh positif dan signifikan secara setatistik. Hal ini menunjukan terdapat perbedaan upah antara yang tamat SD dengan yang tidak tamat, adapun perbedaannya sebesar ln 0,203 atau jika di antilogkan menjadi 1,225. Untuk tamatan 
SMP terdapat pedaan upah sebesar 1,39 kali, tamatan SMA sebesar 2,6 kali dan pendidikan tinggi terdapat peningkatan sebesar 3,6 kali bagi pekerja wanita pedesaan di Sumatera Selatan, jika dibandingkan dengan yang tidak tamat SD. Dapat disimpulkan bahwa, Jika dilihat dari jenjang pendidikan semakin tinggi tingkat pendidikan nilai estimasinya semakin besar. Hal ini berarti semakin tinggi tingkat pendidikan maka nilai rate of returrnnya semakin besar.

Variabel sektor Non pertanian bertanda negatif, hal ini berarti upah yang diterima pekerja wanita yang bekerja disektor non pertanian lebih rendah sebesar $r$ 29,06 persen $(1-0,7004)$ jika dibandingkan yang pekerja wanita yang bekerja disektor pertanian. Hal ini terjadi karena terjadi peningkatan harga komoditi pertanian khususnya karet dan kelapa sawit yang menjadi andalan bagi petani di Sumatera selatan pada tahun tersebut.

$$
\text { Variabel menikah tidak }
$$

berpengaruh secara signifikan terhap upah pekerja wanita pedesaan di Sumatera Selatan. Hal ini disebabkan secara umum pekerja wanita di pedesaan merupakan sebagai pekerja sampingan, sehingga berbeda dengan pekerja laki-laki yang mana pekrjaannya adalah sebagai pekerja utama dalam keluarga sehingga mereka akan mendapatkan tunjangan keluarga. variabel memiliki anak tidak berpengaruh secara signifikan bagi pekerja wanita di pedesaan hal ini dikarenakan walaupun mereka memiliki anak balita, namun tidak mengganggu aktivitas pekerjaan mereka. Karena ketika mereka bekerja anak balita mereka titipakan pada keluarga yang ada di rumah. Bahkan tidak jarang mereka bekerja sambil membawa anaknya.

Variabel memiliki anak untuk pekerja wanita pedesaan di Sumatera Selatan tidak berpengaruh secara signifikan. Hal ini disebabkan dengan kehadiran anak balita tidak berpengaruh baginya dalam bekerja untuk meningkatkan upah. Hal ini diduga ketika mereka sedang bekerja, yang mengasuh dan merawat anaknya diserahkanya pada anggota keluarga lainya.

\subsection{Kesimpulan}

1. Variabel Jam Kerja, usia, Tingkat Pendidikan dan sektor Non petanian berpengaruh secara positif dan signifikan terhadap upah pekerja wanita Pedesaan di Sumatera Selatan.

2. Variabel sektor pekerjaan non pertanian berpengaruh negatif hal ini menunjukan upah yang diterima pekerja wanita yang bekerja di sektor non pertanian lebih rendah dari pekerja wanita pedesaan yang bekerja di sektor pertanian di Sumatera Selatan.

3. Variabel status menikah dan variabel memiliki anak balita tidak berpengaruh secara signifikan terhadap upah pekerja wanita pedesaan di Sumatera Selatan.

\subsection{Saran}

Dari hasil analisa dan pembahasan mengenai faktor-faktor yang mempengaruhi perbedaan upah pekerja wanita pedesaan di Sumatera Selatan, terdapat beberapa saran yang penulis ajukan yaitu:

1. Bagi pemerintah

a. Membangun berbagai fasilitas yang mendukung berkembangnya perekonomian di pedesaan agar lebih tumbuh pekerjaan di sektor non pertanian sehingga pekerja wanita lebih terserap dilapangan pekerjaan non pertanian

b. Memberikan pelatihan dalam rangka meningkatkan SDM pekerja wanita di pedesaan.

c. Membuat kebijakan khusus tentang upah pekerja wanita terutama di sektor informasi 


\section{DAFTAR PUSTAKA}

Alwang, Jand Stalman I. Judith. (1992).Supply and Demandfor married female Labor: Rural and urban Defferences in the Southern United states. Shouthern Journal of Agriculture Economics.

Badan Pusat Statistik Sumatera Selatan. 2014. Keadaan Ketenagakerjaan Agustus 2014. Badan Pusat Statistik Sumatera Selatan, Palembang.

Badan Pusat Statistik Sumatera Selatan. 2013. Situasi Ketenagakerjaan Sumatera Selatan. Badan Pusat Statistik Sumatera Selatan, Palembang.

Becker, G S, 1980, Human Capital; A Theoritical and Empirical Analysis with Special Preferance to Education, The University of Chicago Press, Chicago.

Bellante, D and Jackson, M, 1990. Ekonomi Ketenagakerjaan. Terjemahan oleh:Wimandjaja K. Liotohe dan M. Yasin. Penerbit FE Universitas Indonesia.

Boll, C. 2011. Mind the-gap-German motherhood risks in figures and game theory issues. Int Econ Econ Policy, 8:363-382. doi: 10.1007/s10368-011-0188-x.

Borjas, George J, 2005, Labor Economic Third Edition, Mc Graw Hill Internatioana Edition, Boston.

Cahuc, P and Zylberger, A, 2004, Labor Economics. London, England: The MIT Press.

Ehrenberg, R. G and Robert. S.S, 2003. Modern Labor Economics: Theory and Public Policy International Edition, Boston: Addison Wesley.

E. Hall, 1973.Wages, Income and Hours of work in the U.S. Labor Force In Glen G Cain and Harrold W. Wats ed, Income Maintenance and Labor Supply, Chicago, 102- 62.

Gujarati, Damodar N, 2004, Basic Econometric Fourth Edition, McGrawHill International Edition, New York.

Hakim, Lukmanul. 2011. Perkembangan Tenaga Kerja Wanita Di Sektor Informal: Hasil Analisa dan Proxy Data Sensus Penduduk. Among Makarti, Vol.4 No.7.

Jhingan, M.L, 2004. Ekonomi Pembangunan dan Perencanaan. Jakarta.

Kaufman, Bruce E and Julie L. Hotchkiss, 2003, The Economics of labor market Sixth Edition, Thomson, Shouth-western, Australia.

Killingsworth, M. R and Heckman, J. 1991. Female Labor supply; A survey inHandbook of labor Economics, Vol.1, Ch 2. Edited, orley Ashenfelter and Richard Layard. Ellsevierscience Publisher North-Holland, Amsterdam.

Mincer, J, 1974, Schooling, Experience and Earning. New York: Columbia University Press.

Nakamura., M, Nakamura, A and Dallas, D. (1979). Job Opportunities, the Offered Wage, and The Labor Supply of Married Women. Am. Econ Rev.

Ozdemir R A dkk, 2006. Female Labor Force Participation in informal sector: an ordered logit approach, the empirical Economic letter. 
Pryatno, duwi, 2010, Paham Analisa Statistik Data dengan SPSS, Penerbit Media Kom Yogyakarta.

Reynolds, L. G, 1998, Labor Economic and Labor Relation 11th Ed, New Jersey: Prentice-Hall International Inc.

Tarmizi, Nurlina, 2003, Pemberdayaan Ekonomi Keluarga Melalui Agihan Masa Pekerjaan Wanita: Kajian Kes Selatan Indonesia (Tesis Doktor Faksafah). Universiti Kebangsaan Malaysia, tidak dipublikasikan.
Tarmizi, Nurlina, 2012, Ekonomi Ketenagakerjaan Edisi kedua, Percetakan Universitas Sriwijaya Palembang.

Todaro, M.P, 2000, Pembangunan Ekonomi di Dunia Ketiga, Erlangga Jakarta.

Winter, C and Gndling. H. T. 1992. Women Labor Force Participation and Earning in Honduras. Edited By Psacharopoulus and Tzannatos. Z. World Bank. 